\title{
Studi Kesulitan Belajar Mahasiswa Jurusan Pendidikan IPA dalam Mempelajari Sifat Periodik Unsur
}

\author{
Monica Prima Sari ${ }^{1)}$ Andromeda $^{2)}$ Aristo Hardinata ${ }^{3)}$ \\ ${ }^{1)}$ Jurusan Pendidikan IPA, Universitas Negeri Padang \\ 2) Jurusan Kimia, Universitas Negeri Padang \\ 3) Program Studi Pendidikan IPA, Universitas Negeri Medan \\ primasarimonica@fmipa.unp.ac.id
}

\begin{abstract}
Periodical properties of elements are not a new topic for students in science education department for they have studied this topic previously in senior high school and in General Chemistry course. However, teaching experiences for the past two years in Basic Inorganic Chemistry course revealed that many students still failed to master the expected learning outcomes for this topic. Therefore, this explorative study was conducted to figure out what kind of difficulty that students perceived in learning this topic. One hundred and twelve students in science education department of Universitas Negeri Padang enrolled in Basic Inorganic Chemistry course in the academic year of 2017/2018 were involved as subjects in this study, and data of students' perceived learning difficulties were collected with a questionnaire. Data were analyzed with descriptive statistics technique to map out our findings which will become the fundamental consideration in discussing attempts to overcome students' perceived learning difficulties. Our findings revealed that the sources of students' perceived difficulty came from several factors, namely: the characteristic of content, personal learning style, condition of classroom learning, availability of relevant learning resources and previous learning experiences. Based on these findings, attempts for better learning of periodical properties of elements were suggested.
\end{abstract}

Keywords : Periodical properties of elements, learning difficulty, inorganic chemistry

This is an open access article distributed under the Creative Commons 4.0 Attribution License, which permits unrestricted use, distribution, and reproduction in any medium, provided the original work is properly cited. $@ 2020$ by author and Universitas Negeri Padang.

\section{PENDAHULUAN}

Materi sifat periodik unsur (SPU) terdapat dalam mata kuliah Dasar-dasar Kimia Anorganik (DKAN) yang harus diambil mahasiswa jurusan Pendidikan IPA Universitas Negeri Padang. Merujuk kepada silabus yang disusun, topik materi ini mencakup sifat periodik jari-jari atom dan ion, energi ionisasi, afinitas elektron, dan keelektronegatifan. Secara garis besar, materi SPU merupakan pengulangan dari materi dengan judul yang sama pada mata kuliah Kimia Umum yang diikuti mahasiswa sebelumnya. Namun, dibalik judul yang sama ini, terdapat beberapa pendalaman dan penekanan materi SPU yang diberikan dalam mata kuliah DKAN.

Sebagai mata kuliah wajib program studi, mata kuliah ini diharapkan dapat mendukung kompetensi profesional mahasiswa calon guru IPA untuk mengajar materi yang relevan di SMP seperti materi atom, ion, dan molekul. Di samping pendalaman dan penekanan pada beberapa konsep, perbedaan materi ini dengan mata kuliah Kimia Umum adalah diselipkannya kompetensi yang menuntut keterampilan berpikir kritis dan logis mahasiswa serta kemampuan menyusun scientific explanation untuk fenomena alam yang relevan. Untuk lebih lengkapnya, Tabel 1 berikut memaparkan kemampuan akhir yang diharapkan dari materi SPU dalam mata kuliah DKAN.

Tabel 1. Kemampuan akhir yang diharapkan (KAD) dari materi SPU
Label $^{*}$

Kemampuan

akhir yang

diharapkan

KAD -1

KAD -2

KAD-3

KAD-4

KAD-5
Deskripsi Kemampuan akhir yang diharapkan

Menjelaskan sifat periodik jari-jari Atom dan ion unsur-unsur dalam tabel periodik.

Menjelaskan konsep Shielding Effect dan hubungannya dengan jari-jari atom dan ion.

Menghitung muatan inti efektif dan menjelaskan hubungan nilainya dengan sifat periodik jari-jari atom dan ion. keperiodikan dari energi ionisasi pertama dan kedua untuk unsur golongan alkali dan alkali tanah. Menjelaskan hubungan sifat keperiodikan energi ionisasi unsur
Menjelaskan konsep dan sifat 


\begin{tabular}{cc}
$\begin{array}{c}\text { Label*) } \\
\text { Kemampuan } \\
\text { akhir yang } \\
\text { diharapkan }\end{array}$ & \multicolumn{1}{c}{$\begin{array}{c}\text { Deskripsi Kemampuan akhir yang } \\
\text { diharapkan }\end{array}$} \\
\hline & $\begin{array}{l}\text { golongan alkali dan alkali tanah dengan } \\
\text { konsep muatan inti efektif. }\end{array}$ \\
KAD-6 & $\begin{array}{l}\text { Menjelaskan konsep afinitas elektron } \\
\text { dan sifat keperiodikannya. }\end{array}$ \\
KAD-7 & $\begin{array}{l}\text { Menjelaskan konsep keelektronegatifan } \\
\text { dan sifat keperiodikannya. }\end{array}$ \\
*) Pelabelan ini hanya dimaksudkan untuk memudahkan penya- \\
jian data temuan penelitian.
\end{tabular}

Berdasarkan hasil observasi sejak tahun 2016, menunjukkan bahwa belum seluruh mahasiswa mampu menguasai kemampuan akhir yang diharapkan di atas dengan baik. Hal ini menarik bagi peneliti karena materi SPU telah dipelajari mahasiswa sebelumnya pada mata pelajaran kimia di SMA dan pada mata kuliah Kimia Umum (bagian dari mata kuliah bersama tingkat fakultas). Seharusnya tidak sulit lagi bagi mahasiswa untuk menguasai kemampuan akhir yang diharapkan dari mata kuliah DKAN karena sudah dua kali dipelajari.

Penelitian relevan telah menemukan bahwa kimia dipandang sebagai subyek yang sulit dipahami di kalangan mahasiswa (Chiu, 2005; Sirhan, 2007). Sebagai bagian dari kajian ilmu kimia, materi SPU tidak terlepas dari sifatnya yang abstrak dan kompleks (Gabel, 1999; Taber, 2009; Talanquer, 2011; Atagana \& Engida, 2014) yang menyebabkan mahasiswa tidak begitu percaya diri dalam mempelajari kimia. Untuk memahami konsep kimia dengan baik, sering kali mahasiswa perlu memahami bahasa simbolik yang digunakan dalam pengajaran untuk dimaknai dan digunakannya untuk memahami apa yang terjadi pada level mikroskopis (Taber, 2008; Talanquer, 2011), kemudian menerapkannya untuk menjelaskan fenomena makroskopis (Chiu, 2005).

Di samping itu, pengajaran konsep kimia selama ini sering menerapkan rote learning atau belajar hafalan, dan keberhasilan belajar dinilai berdasarkan kemampuan menyajikan kembali hafalan tersebut saat tes (Yiin, 2010). Konsekuensinya adalah konsep-konsep dalam Kimia yang abstrak tersebut oleh kebanyakan mahasiswa diterima sebagai sekumpulan informasi yang harus dihafal dan dituliskan kembali saat penilaian; tidak merasa perlu untuk memahami konsepnya.

Materi SPU sering dipandang sebagai materi yang sarat dengan pengetahuan faktual yang membutuhkan kemampuan menghafal yang baik. Beberapa penelitian telah dilakukan terkait kesulitan belajar untuk toik ini, baik untuk tingkat SMA (Satilmis, 2014) yang menitikberatkan pada strategi penyampaian materi selama pembelajaran; atau SMP (Kousa, Kavonius, \& Aksela, 2018); maupun tingkat universitas (Salame, Sarowar, Begum, \& Krauss, 2011); (Mokiwa, 2017) yang menitikberatkan pada miskonsepsi yang dimiliki mahasiswa terkait materi SPU. Untuk konteks mahasiswa di luar jurusan Kimia, penelitian menunjukkan bahwa motivasi dan partisipasi mahasiswa meningkat untuk mata kuliah yang melibatkan praktikum dan menurun untuk kuliah tatap muka yang membahas teori dan prosedur (Çalik, Ültay, Kolomuç, \& Aytar, 2015).

Mata kuliah DKAN bertujuan membekali mahasiswa jurusan Pendidikan IPA dengan pengetahuan dan keterampilan berpikir yang memadai untuk mengajar topik yang relevan (seperti: atom, ion, dan molekul) sebagai calon guru IPA di SMP. Meskipun kajian materinya secara umum tidak begitu dalam, namun pemahaman yang baik dapat membantu mahasiswa menjelaskan feno-mena alam dengan lebih konseptual ketika bertugas nanti (Holbrook, 2005). Misalnya, ketika mahasiswa harus mengajar topik lintas disiplin ilmu seperti pemasanan global, pencemaran lingkungan, dan teknologi ramah lingkungan. Penjelasan yang baik menuntut mahasiswa untuk menghubungkan beberapa konsep dan prosedur, yang memang seharusnya dilatihkan di tingkat universitas (Manneh, 2019).

Belum maksimalnya hasil belajar mahasiswa jurusan Pendidikan IPA menunjukkan adanya kendala atau kesulitan yang dirasakan. Kesulitan ini merupakan bagian dari ranah afektif yang turut mempengaruhi keberhasilan belajar mahasiswa secara keseluruhan (Cheung, 2011; Hofstein \& Mamlok-Naaman, 2011; Galloway, Malakpa, \& Bretz, 2016) Oleh sebab itu, peneliti bermaksud untuk melakukan menggali kesulitan tersebut, dimana temuan studi ini nantinya diharapkan dapat menjadi dasar bagi tim KBK Kimia di jurusan Pendidikan IPA dalam merumuskan upaya meningkatkan pembelajaran materi ini di masa yang akan datang.

\section{METODE PENELITIAN}

Penelitian ini merupakan penelitian deskriptif yang bertujuan menggali sebanyak mungkin informasi terkait kesulitan belajar yang dialami 
mahasiswa. Untuk mencapai tujuan ini, instrumen yang digunakan untuk mengumpulkan data adalah kuesioner yang berisi pertanyaan terbuka dan tertutup tentang kesulitan belajar mahasiswa, dan disebarkan kepada seluruh mahasiswa jurusan Pendidikan IPA FMIPA Universitas Negeri Padang yang mengambil mata kuliah DKAN pada tahun akademik 2017/2018. Respon dari mahasiswa tersebut kemudian dianalisis dengan menggunakan teknik statistika deskriptif untuk memudahkan penyajian informasi yang diperoleh.

\section{HASIL DAN PEMBAHASAN}

Berdasarkan hasil analisis terhadap respon mahasiswa, kami menemukan beberapa informasi berikut ini.

\section{Pengulangan materi tidak menjamin kemudahan menguasai kemampuan akhir yang diharapkan untuk materi SPU.}

Sebelum mempelajari materi SPU dalam mata kuliah DKAN, mahasiswa boleh jadi sudah memiliki konsepsi sendiri berdasarkan apa yang pernah dipelajari sebelumnya; (Sirhan, 2007;Taber, 2008). Ketika konsepsi ini berbeda dengan yang mereka pelajari sekarang, proses kontruksi pengetahuan dapat terganggu (Özmen, 2008). Ada dua kemungkinan yang dapat terjadi, yaitu apakah mahasiswa tersebut mampu mengakomodasi pengetahuan baru dan mengubah pengetahuan lama yang tidak sesuai, atau justru menolak pengetahuan baru dan bertahan dengan pengetahuan lama (Taber, 2008). Ketika pilihan kedua ini terjadi, berarti mahasiswa memaknai pengetahuan baru yang diterima berdasarkan pemahaman mereka sendiri, yang belum tentu benar (Taber, 2009). Dengan kata lain, mahasiswa dapat dikatakan mengalami miskosepsi atau memiliki konsepsi alternatif.

Melalui kuesioner yang diberikan kepada mahasiswa, kami menanyakan apakah pengulangan mempelajari materi SPU yang mereka alami (di SMA dan pada mata kuliah Kimia Umum di tahun pertama kuliah) dapat membantu atau memudahkan mereka mempelajari materi yang sama pada mata kuliah DKAN. Hasilnya, sebagian besar mahasiswa (84.2\%) sangat terbantu dengan pengulangan materi SPU. Namun, temuan ini berlawanan dengan temuan kami dari hasil belajar mahasiswa. Belum maksimalnya hasil belajar mahasiswa terkait materi ini menunjukkan bahwa pengulangan materi SPU tersebut tidak terlalu banyak membantu. Temuan yang patut dicermati adalah adanya sebagian kecil mahasiswa (6.1\%) yang malah menjadi semakin bingung dalam mempelajari materi SPU dalam mata kuliah DKAN, dan sebagian lainnya (9.6\%) justru tidak merasa terbantu.

Untuk memahami alasan dibalik respon "malah menjadi semakin bingung", kami menganalisis lebih lanjut respon kelompok mahasiswa tersebut. Kami menemukan bahwa penyebabnya adalah: a) kesulitan memahami buku referensi berbahasa Inggris; b) tidak mampu mengikuti alur pembelajaran di kelas dengan baik; c) kurangnya buku referensi berbahasa Indonesia yang dapat dijumpai di perpustakaan; d) tidak memahami materi SPU dari SMA; e) tidak menguasai konsep dasar Kimia dari awal; f) kesulitan mengingat atau menghafal nama dan nomor atom unsur.

Dari keenam penyebab di atas, tersirat bahwa penyebab dibalik merasa tidak terbantunya mahasiswa dengan pengulangan materi SPU dapat berasal dari beberapa sumber, yaitu diri mahasiswa sendiri, pengalaman belajar sebelumnya, kondisi pembelajaran/ perkuliahan, dan ketersediaan sumber belajar berbahasa Indonesia yang relevan. Sumber penyebab dari kondisi perkuliahan dan ketersediaan reverensi sejalan dengan temuan penelitian Atagana \& Engida (2014) yang memang terbukti berkontribusi terhadap kesulitan belajar mahasiswa.

\section{Konsep materi SPU yang sulit dipahami mahasiswa}

Materi SPU mengandung banyak konsep dan pengetahuan faktual serta pengetahuan prosedural serta perhitungan matematis. Pengalaman mengajar selama dua tahun mengungkap bahwa ada enam konsep yang sulit dipahami mahasiswa di setiap tahunnya. Maka dari itu, kami meminta mahasiswa memilih konsep yang dirasa paling sulit dipahami di antara keenam konsep tersebut, dimana satu mahasiswa boleh memilih lebih dari satu konsep. Respon mahasiswa dapat dilihat pada Diagram 2. Sebanyak 62.4\% mahasiswa kesulitan menguasai konsep Shielding Effect atau efek perisai. Berikutnya, $\mathbf{4 4 . 4 \%}$ mahasiswa menyatakan sulit menguasai konsep energi ionisasi pertama dan kedua. Selanjutnya, konsep yang paling sulit dipahami adalah afinitas elektron, keelektronegatian, muatan inti efektif, dan terakhir jari-jari atom dan ion. 
Munculnya konsep jari-jari atom dan ion sebagai konsep dengan persentase terkecil mengindikasikan boleh jadi mahasiswa merasa paling percaya diri dapat memahami konsep ini. Hal ini terlihat dalam proses pembelajaran dimana sebagian besar mahasiswa dapat dengan mudah menjawab pertanyaan tentang definisi jari-jari atom dan ion serta sifat periodiknya. Untuk melihat apakah penguasaan konsep mahasiswa tersebut sudah benar atau belum, diperlukan studi lanjutan yang lebih mendalam.

Tabel 2. Konsep materi SPU yang paling sulit dipahami menurut mahasiswa.

\begin{tabular}{llc} 
No. & $\begin{array}{l}\text { Konsep materi SPU } \\
\text { yang diduga sulit } \\
\text { bagi mahasiswa }\end{array}$ & $\begin{array}{l}\text { Jumlah } \\
\text { yang } \\
\text { sulit memahami (\%) }\end{array}$ \\
\hline 1. & Shieling effect & $\begin{array}{r}\text { mahasiswa } \\
\text { menyatakan }\end{array}$ \\
2. & Energi ionisasi & $44,4 \%$ \\
& pertama dan kedua & \\
3. & Afinitas elektron & $35,9 \%$ \\
4. & Keelektronegatifan & $29,1 \%$ \\
5. & Muatan Inti Efektif & $23,9 \%$ \\
6. & Jari-jari atom dan & $15,4 \%$ \\
& ion \\
\hline
\end{tabular}

*)Catatan: mahasiswa boleh memilih lebih dari sa konsep

Konsep shielding effect yang muncul sebagai konsep yang dirasa paling sulit dipahami dapat dimaklumi karena konsep ini relatif baru, belum dipelajari di SMA dan hanya disinggung sedikit dalam mata kuliah Kimia Umum. Pada dasarnya, konsep ini sangat penting untuk menjelaskan kecenderungan sifat periodik jarijari atom, terutama mengenai jari-jari atom unsur seperiode yang makin kecil dari kiri ke kanan dalam tabel periodik. Mengingat pentingnya konsep ini untuk konstruksi pengetahuan mahasiswa, kesulitan belajar mahasiswa perlu segera diatasi.

Hal yang cukup kontradiktif adalah konsep muatan inti efektif -yang sangat berkaitan dengan konsep shielding effect- berada di urutan kelima dari enam konsep yang ada. Dengan kata lain, di luar jumlah $23.9 \%$, mahasiswa tidak kesulitan memahami konsep muatan inti efektif. Di satu sisi, ini dapat bermakna positif bahwa mungkin mahasiswa mudah memahami penjelasan dari dosen yang mengajar konsep muatan inti efektif. Namun, di sisi lain kami menyadari bahwa mahasiswa masih kesulitan memahami konsep shielding effect yang seharusnya menjadi bagian tak terpisahkan dari pemahaman tentang muatan inti efektif. Temuan ini jelas menyiratkan bahwa proses pembelajaran kedua konsep ini harus lebih menekankan hubungan antara keduanya untuk membangun pemahaman mahasiswa yang lebih komprehensif.

Temuan menarik lainnya adalah $44.4 \%$ mahasiswa memilih energi ionisasi pertama dan kedua sebagai konsep yang paling sulit dikuasai. Padahal dari pengalaman mengajar di kelas, sebagian besar siswa tidak kesulitan menjawab ketika ditanya apa itu energi ionisasi. Namun, ketika diminta menjelaskan perbedaan data EI pertama dan kedua untuk unsur golongan IA dan IIA (salah satu indikator KAD-4), tidak ada mahasiswa yang mampu menjawab dengan benar. Hal ini bisa jadi mengindikasikan bahwa mahasiswa sebagai mengingat/ mengetahui definisi dari energi ionisasi namun tidak memahami maknanya.

Indikasi yang sama juga berlaku untuk konsep afinitas elektron. Sebagian besar mahasiswa tidak kesulitan menjawab pertanyaan “apa itu afinitas elektron?". Namun, ketika soal (ujian atau kuis) sudah dirancang sedemikian rupa agar mahasiswa mampu mengelaborasi lebih dal-am (misalanya apa artinya jika suatu unsur memiliki afinitas elektron yang besar?) dan menerapkan konsep ini pada konteks atau soal berbasis keterampilan berpikir tingkat tinggi, hampir setengah dari seluruh mahasiswa tidak mampu menjawab dengan benar.

\section{KAD materi SPU yang paling sulit dikuasai mahasiswa}

Kimia adalah suatu bidang ilmu yang menantang dan berharga untuk dipelajari karena bidang ini memperkenalkan seni berpikir kritis, cara merumuskan masalah sekaligus menyelesaikannya, serta mampu mengasah keterampilan proses pembelajarnya (Emendu, N.B., Okoye, 2015). KAD yang disusun oleh tim KBK kimia jurusan Pendidikan IPA mengarahkan proses pembelajaran pada penguasaan keterampilan berpikir tingkat tinggi mahasiswa. Dari seluruh KAD yang dirancang untuk materi SPU (Tabel 1), kami meminta mahasiswa menyatakan KAD mana yang dirasa paling sulit untuk dikuasai. Satu mahasiswa dapat memilih lebih dari satu KAD jika memang mereka merasa sulit menguasainya. Hasil analisis respon mahasiswa dapat dilihat dalam Diagram 1.

Diagram 1 menunjukkan bahwa KAD-2 yaitu menjelaskan konsep Shielding Effect dan hubungannya dengan jari-jari atom dan ion. Lebih dari setengah dari total subyek penelitian ini menyatakan KAD-2 adalah yang paling sulit 
dipahami. Hal yang menarik di sini adalah konsep jari-jari atom dan ion berada di urutan paling akhir diantara konsep yang dirasa sulit oleh mahasiswa. Artinya, sebagian besar siswa tidak kesulitan memahami konsep ini. Namun, ketika harus menjelaskan kecenderungan sifat periodik ukuran atom dan ion dengan konsep shielding effect, sebagian besar mahasiswa tidak mampu menjawab dengan benar. Kemungkinannya, hal ini disebabkan karena konsep shielding effect adalah konsep yang paling sulit dikuasai, yang relatif baru bagi mahasiswa, dan sifatnya abstrak. Konsep shielding effect membahas interaksi antar elektron dalam atom yang tak kasat mata. Artinya, untuk menguasai KAD ini, mahasiswa harus berusaha memahami atom pada tingkat mikroskopis dan menghubungkan pemahaman tersebut dengan beberapa konsep terkait, kemudian membangun pemahaman yang baru yang lebih komprehensif tentang ukuran atom dan ion.

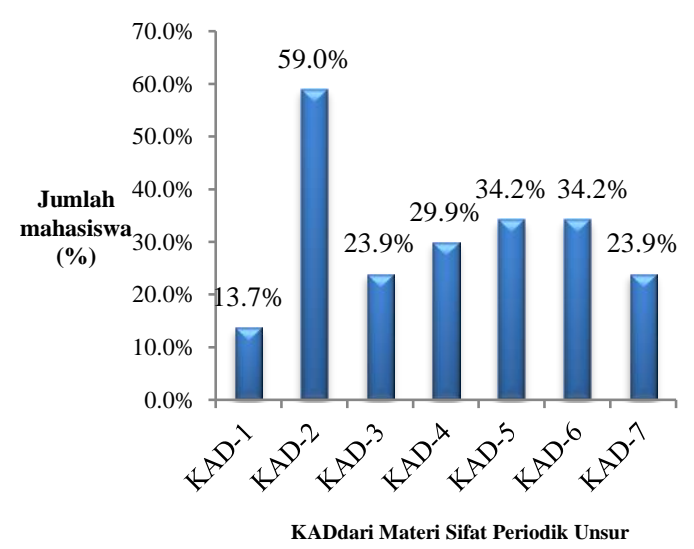

Diagram 1. Pendapat mahasiswa mengenai kemampuan akhir yang diharapkan (KAD) dari materi SPU yang dirasa sulit dikuasai

Menurut teori belajar konstruktivisme, mahasiswa harus melalui proses belajar yang sifatnya mandiri dan kontinu dalam membangun pengetahuan (Taber, 2008), yaitu sejak awal mereka mengenal konsep kimia hingga kini. Mahasiswa perlu terus menyesuaikan pemahaman lama dengan pemahaman baru, yang mereka konstruksi sendiri dari proses pembelajaran. Penjelasan terkait sifat periodik ukuran atom dan ion yang umum ditemui/didengar adalah bahwa: "untuk unsur segolongan, ukuran atom semakin meningkat dari atas ke bawah karena pertambahan jumlah kulit atom, dan untuk unsur seperiode ukurannya semakin mengecil dari kiri ke kanan karena pertambahan elektron yang terdapat pada jumlah kulit yang sama." Sebagian besar mahasiswa terlihat "puas" dengan penjelasan ini, namun berbeda halnya jika ditanya terkait penyebab dibalik sifat periodik tersebut. Penelitian yang dilakukan oleh (Salame et al., 2011) menemukan bahwa $80 \%$ mahasiswa cenderung menghafal sifat periodik terkait jarijari atom ini, sehingga ketika diminta menjelaskan lebih rinci, mereka tidak mampu. Hal ini juga kami temui di antara mahasiswa jurusan Pendidikan IPA.

Dalam mata kuliah DKAN, Tim KBK Kimia sepakat untuk memberikan pendalaman materi dari yang pernah dipelajari mahasiswa sebelumnya. Untuk materi SPU, shielding effect dan muatan inti efektif adalah bagian dari pendalaman tersebut. Ekspektansi yang ingin dicapai adalah munculnya penjelasan yang lebih konseptual terhadap sifat periodik unsur yang mampu disusun mahasiswa. Namun, dengan temuan penelitian ini, jelas perlu adanya suatu upaya dalam melaksanakan pembelajaran, agar KAD-2 ini tidak lagi sulit dicapa mahasiswa.

KAD berikutnya yang paling sulit dikuasai mahasiswa adalah KAD-5 (menjelaskan hubungan sifat keperiodikan energi ionisasi unsur golongan alkali dan alkali tanah dengan konsep muatan inti efektif) dan KAD-6 (menjelaskan konsep afinitas elektron dan sifat keperiodikannya). Muatan inti efektif dinyatakan sebagai konsep yang sulit hanya oleh seperlima dari total 112 mahasiswa. Artinya, sebagian besar mahasiswa tidak kesulitan memahami konsep ini. Namun, ketika harus menghubungkan pemahaman terhadap konsep ini dengan konsep energi ionisasi, kami menemukan bahwa banyak siswa mengalami kesulitan. Padahal, usaha dalam menguasai KAD-2 merupakan "sarana" untuk melatih keterampilan berpikir tingkat tinggi mahasiswa.

Berbeda dengan KAD-5, KAD-6 sepertinya berkaitan dengan dinyatakannya konsep afinitas elektron sebagai konsep yang paling sulit dipahami pada urutan ketiga. Kami menduga bahwa kurangnya pemahaman mendasar terhadap konsep ini menyebabkan siswa kesulitan menguasai KAD terkait. Temuan ini menguatkan temuan sebelumnya bahwa pengulangan materi SPU di SMA dan di mata kuliah Kimia Umum tidak begitu membantu dalam hal membangun pemahaman siswa. 


\section{Pendapat mahasiswa mengenai penyebab sulitnya memahami materi SPU}

Dari total 112 responden kuesioner yang kami berikan, terdapat beberapa penyebab sulitnya mahasiswa memahami materi SPU yang dapat dilihat dalam Tabel 3. Hasil analisis respon mahasiswa mengarahkan kami pada empat sumber utama penyebab sulitnya mahasiswa memahami materi SPU, yaitu a) pengalaman belajar masa lalu; b) karakter dan gaya belajar personal mahasiswa; c) karakteristik materi sifat periodik unsur; serta d) kondisi kelas, suasana pembelajaran dan ketersediaan buku referensi yang relevan.

Tabel 3. Kesulitan yang dirasakan mahasiswa dalam mempelajari materi SPU.

\begin{tabular}{|c|c|c|}
\hline No. & $\begin{array}{l}\text { Penyebab kesulitan belajar menurut } \\
\text { mahasiswa }\end{array}$ & $\begin{array}{l}\text { Jumlah } \\
\text { mahasiswa } \\
(\%)\end{array}$ \\
\hline 1. & $\begin{array}{l}\text { Ketidakmampuan untuk mengikuti alur } \\
\text { pembelajaran di kelas dengan baik. }\end{array}$ & $12.5 \%$ \\
\hline 2. & $\begin{array}{l}\text { Kurangnya pemahaman mahasiswa } \\
\text { terkait materi saat dipelajari di SMA }\end{array}$ & $6.3 \%$ \\
\hline 3. & $\begin{array}{l}\text { Kurangnya penguasaan terhadap } \\
\text { konsep-konsep esensial Kimia dan yang } \\
\text { relevan dengan materi SPU }\end{array}$ & $8.9 \%$ \\
\hline 4. & $\begin{array}{l}\text { Kurangnya buku/ referensi yang relevan } \\
\text { dengan materi SPU yang dipelajari. }\end{array}$ & $11.6 \%$ \\
\hline 5. & $\begin{array}{l}\text { Kesulitan menghafal unsur-unsur dalam } \\
\text { tabel periodik beserta sifat unsur per } \\
\text { golongan dan periode. }\end{array}$ & $15.2 \%$ \\
\hline 6. & $\begin{array}{l}\text { Kurang memahami konsep dari materi } \\
\text { SPU; materi sulit dipahami; terlalu } \\
\text { banyak; rumit }\end{array}$ & $31.3 \%$ \\
\hline 7. & $\begin{array}{l}\text { Kondisi kelas panas, jam perkuliahan di } \\
\text { siang hari; kurang fokus dalam } \\
\text { perkuliahan }\end{array}$ & $9.8 \%$ \\
\hline 8. & $\begin{array}{l}\text { Buku-buku referensi berbahasa Inggris } \\
\text { yang sulit dipahami }\end{array}$ & $7.1 \%$ \\
\hline 9. & $\begin{array}{l}\text { Jarang/ tidak mengulang materi yang } \\
\text { dipelajari di SMA/ Kimia Umum; } \\
\text { kurang membaca }\end{array}$ & $13.4 \%$ \\
\hline 10. & $\begin{array}{l}\text { Kesulitan mengingat Aturan Slater; } \\
\text { mengerjakan soal perhitungan } \\
\text { matematis }\end{array}$ & $4.5 \%$ \\
\hline 11. & Karakter dan gaya belajar personal & $2.7 \%$ \\
\hline
\end{tabular}

Penyebab yang mendominasi di kalangan mahasiswa adalah dari faktor karakteristik materi SPU yang dikemukakan oleh $\mathbf{4 6 . 5 \%}$ secara total. Dari jumlah ini, sebanyak $31.3 \%$ mahasiswa mengemukakan bahwa materi SPU itu terlalu banyak, rumit, dan sulit dipahami, sementara $15.2 \%$ lainnya menyatakan banyaknya unsur berikut sifatnya per golongan dan per periode yang harus dihafal membuat materi ini menjadi sulit untuk dipahami. Temuan ini tidaklah terlalu mengherankan, karena hal serupa juga ditemukan dalam penelitian di Afrika (Jegede, 2007). Dari sisi pengajaran pun, tidaklah mudah untuk mengajarkan sesuatu yang tidak dapat dilihat oleh mata atau setidaknya memiliki kemiripan dengan benda kasat mata yang ada di alam (Yiin, 2010). Mengajar materi juga berkaitan dengan memilih strategi mengajar mana yang paling efektif untuk membelajarkan mahasiswa dengan mempertimbangkan pengetahuan awal minimal apa yang harus dimiliki mahasiswa (Mokiwa, 2017).

Keberagaman pengetahuan awal yang dimiliki mahasiswa dapat diibaratkan sebagai starting point yang berbeda dalam suatu lomba lari. Mahasiswa dengan pengetahuan awal yang baik dapat mengikuti pembelajaran tanpa ada kendala berarti. Sebaliknya, mahasiswa dengan pengetahuan awal yang tidak memadai mengalami berbagai kendala, dan cenderung merasa bahwa pembelajaran berlangsung terlalu cepat. Penjelasan ini berkaitan dengan temuan bahwa sebanyak $\mathbf{1 2 . 5 \%}$ mahasiswa kesulitan karena tidak mampu mengikuti alur pembelajaran di kelas dengan baik. Secara lebih spesifik, sebagian dari mahasiswa ini menyatakan proses pembelajaran dirasa terlalu cepat dan tidak mampu memahami penjelasan dosen dengan baik.

Mengenai masalah sulitnya menghafal nama dan nomor atom unsur serta sifatnya, hal ini ada hubungannya dengan keterbatasan kapasitan memori kerja manusia (Daniel Tan, Goh, Chia, \& Treagust, 2001; Sirhan, 2007). Akibatnya, mahasiswa perlu mencari cara untuk mengorganisir materi yang menurut mereka perlu dihafal, yang pada dasarnya sudah ada sejak mereka SMA. Telah ada beberapa "jembatan keledai" atau strategi mnemonic yang diajarkan oleh guru atau dosen kimia kepada mahasiswa untuk membantu mengingat pengetahuan faktual dalam materi SPU. Namun, keberhasilan dan efektifitas strategi ini tentu kembali kepada individu mahasiswa masing-masing. Penyimpanan informasi di memori kerja sifatnya hanya sementara. Agar dapat tersimpan di memori jangka panjang, informasi ini perlu diolah dalam berbagai proses berpikir (Sirhan, 2007).

Selanjutnya, sebanyak $\mathbf{1 3 . 4 \%}$ mahasiswa menyatakan bahwa mereka kesulitan memahami materi memang karena tidak pernah atau jarang mengulang materi yang sudah dipelajari sebelumnya, baik di SMA maupun di mata kuliah Kimia Umum. Sejumlah kecil mahasiswa dari bahkan menyatakan tidak pernah mencatat 
selama mengikuti perkuliahan DKAN, sehingga ti-dak dapat mengulang materi kecuali melalui handout yang diberikan dosen. Beberapa mahasiswa lainnya (2.7\%) menyatakan bahwa mereka tidak tertarik mempelajari materi SPU lebih lanjut karena sudah merasa cukup atau puas dengan apa yang sudah mereka ketahui dari pengalaman belajar di SMA dan di Kimia Umum sebelumnya. Perilaku mahasiswa yang tidak mengulang materi, tidak mencatat, tidak tertarik pada materi dapat berhubungan dengan persepsi atau sikap terhadap ilmu Kimia itu sendiri (Holbrook, 2005). Perlu studi lebih lanjut untuk memastikan hal ini.

Pemahaman yang tidak terbangun dengan memadai dari pengalaman belajar sebelumnya juga menjadi penyebab kesulitan belajar mahasiswa (Nakhleh, 1992). Sebanyak 8,9\% mahasiswa menyatakan bahwa mereka tidak menguasai konsep dasar Kimia yang relevan dengan materi SPU, sehingga ketika mempelajari SPU pada mata kuliah DKAN, mereka seolah tidak memiliki starting point atau pengetahuan awal yang memadai. Selanjutnya, sebanyak 6.3\% mahasiswa menyatakan bahwa mereka memang kurang menguasai atau memahami materi SPU sejak SMA, dan hal ini seolah menjadi "penghalang" dalam pikiran mahasiswa untuk mencoba mempelajari materi SPU lebih lanjut.

Tidak hanya dari karakteristik materi dan personal diri mahasiswa, penyebab kesulitan belajar materi SPU juga ada yang bersifat eksternal. Sebanyak 9.8\% mahasiswa mengaku sulit untuk fokus selama pembelajaran di kelas dikarenakan suasanya yang panas. Hal ini sulit dipungkiri karena seluruh kelas mata kuliah DKAN memang dijadwalkan pada siang hari, yang rentan diwarnai dengan rasa lelah atau kantuk mahasiswa. Temuan ini sesuai dengan temuan Kaptan \& Timurlenk (2012) dan Atagana \& Engida (2014) yang menyatakan kelas besar dan kondisi ruang kelas merupakan beberapa diantara faktor dibalik kesulitan belajar kimia.

Penyebab eksternal lainnya adalah ketersedian buku referensi yang relevan, yang dikemukakan oleh $\mathbf{1 1 . 6 \%}$. Klasik memang, tetapi menyediakan buku referensi yang benar-benar sesuai dengan silabus perkuliahan adalah suatu hal yang sulit dilakukan. Di awal perkuliahan DKAN, mahasiswa telah diperkenalkan dengan daftar buku referensi yang dapat digunakan. Beberapa dari referensi tersebut tersedia dalam bentuk buku teks, sementara sebagian lainnya dalam bentuk e-book yang dapat diakses gratis. Namun masalahnya, tidak semua buku ini ditulis dalam bahasa Indonesia, yang merupakan penyebab kesulitan belajar yang dikemukakan oleh $\mathbf{7 . 1 \%}$ mahasiswa. Kurangnya sumber belajar ini juga menjadi faktor dibalik kesulitan belajar yang ditemuan oleh Atagana \& Engida (2014).

Kemampuan memahami buku teks berberbahasa Inggris adalah salah satu masalah yang umum bagi mahasiswa di Universitas Negeri Padang, termasuk di jurusan Pendidikan IPA. Dengan layanan akses internet yang disediakan oleh kampus, mahasiswa tidaklah kesulitan mendapatkan seluruh e-book untuk mata kuliah DKAN. Namun, tanpa kemampuan bahasa Inggris untuk memahami isi buku tersebut, ketersediaan e-book tadi menjadi tidak begitu membantu.

Layanan akses internet gratis di kampus sebenarnya juga dapat memudahkan mahasiswa memperoleh referensi berbahasa Indonesia yang relevan dengan materi perkuliahan. Namun, kebanyakan dari materi tersebut tidak benarbenar sesuai dengan KAD yang ingin dicapai. Dengan kondisi seperti ini, mahasiswa cenderung mengandalkan handout materi dari file power point yang disampaikan dosen di kelas dan tidak ingin berusaha mencari referensi tambahan lainnya.

\section{Rekomendasi untuk pembelajaran materi SPU}

Temuan dari penelitian ini mengindikasikan bahwa penyebab kesulitan belajar mahasiswa untuk materi SPU berkaitan antara satu dengan lainnya. Untuk item kuesioner yang menanyakan penyebab kesulitan mempelajari materi SPU, hampir seluruh mahasiswa mengemukakan lebih dari satu penyebab. Dengan mencermati respon satu mahasiswa untuk seluruh item kuesioner, kami seolah mendapat gambaran yang lebih komprehensif mengenai kesulitan belajar mahasiswa tersebut.

Misalnya, pada satu kasus seorang mahasiswa mengemukakan bahwa penyebab kesulitan belajarnya adalah materi SPU terlalu banyak, sulit menghafal nama dan nomor atom unsur berikut sifatnya, kurang memahami saat belajar di SMA, pembelajaran di kelas terlalu cepat, dan tidak adanya buku sumber berbahasa Indonesia yang relevan. Kasus ini menunjukkan kesulitan belajar yang sudah terakumulasi dari 
pengalaman belajar sebelumnya. Kasus seperti ini pun, dimana mahasiswa mengeluhkan padatnya materi dan gaya mengajar dosen, cukup umum ditemukan dalam penelitian serupa (Atagana \& Engida, 2014) .

Menghafal nama dan nomor atom unsur bukanlah tuntutan atau prasyarat utama untuk menguasai seluruh KAD materi SPU. Namun jika hafal, tentunya dapat membantu dalam pembelajaran. Kami menduga, mahasiswa ini menjadikan pengalaman belajar sebelumnya yang kurang berhasil, banyaknya unsur dalam tabel periodik yang dirasa perlu dihafal dan ketidaan referensi berbahasa Indonesia sebagai alasan untuk tidak berusaha lebih keras, sehingga merasa pembelajaran di kelas terlalu cepat untuk diikuti. Dugaan ini perlu diteliti lebih lanjut untuk memastikan kesulitan belajar yang dialami mahasiswa ini.

Bertolak dari temuan penelitian ini, kami merekomendasikan beberapa upaya berikut untuk dilakukan dalam pembelajaran yang mendatang.

a) Optimalisasi fasilitas ruang perkuliahan untuk mengatasi suhu udara yang panas saat perkuliahan dijadwalkan di siang hari.

b) Penekanan pentingnya pemahaman terhadap aspek metakognitif yang ikut menentukan keberhasilan belajar mahasiswa, terutama terkait cara belajar individu. Ini perlu dilakukan di awal perkuliahan untuk mengurangi asumsi atau persepsi negatif yang mahasiswa miliki terkait materi SPU atau materi DKAN secara keseluruhan.

c) Penyesuaian metode pengajaran dan alur proses pembelajaran saat tatap muka agar mampu mempertahankan fokus mahasiswa, tidak terkesan monoton, dan dapat memberi waktu lebih lama untuk membahas konsep yang paling sulit dikuasai mahasiswa, konsep yang membutuhkan pembentukan koneksi dengan konsep lain, atau konsep yang sudah dipelajari sebelumnya.

d) Penyusunan materi atau bahan ajar berbahasa Indonesia yang disesuaikan dengan tuntutan silabus, kemampuan akhir yang diharapkan, keterampilan berpikir tingkat tinggi yang akan dilatihkan, serta konteks penerapan yang sesuai dengan ciri program studi Pendidikan IPA.

\section{KESIMPULAN}

Penelitian ini menemukan bahwa penyebab kesulitan belajar yang dirasakan mahasiswa dapat berasal dari beberapa sumber, yaitu: karakteristik materi SPU, karakter dan gaya belajar personal mahasiswa, kondisi/ suasanya perkuliahan dan ketersediaan buku referensi yang relevan, dan pengalaman belajar sebelumnya. Upaya yang dapat dilakukan untuk pembelajaran materi SPU yang akan datang antara lain: optimalisasi fasilitas ruang perkuliahan untuk mengatasi suhu udara yang panas di siang hari, penekanan aspek metakognitif agar mahasiswa mampu memaksimalkan cara belajarnya sendiri, penyesuaian metode dan alur proses pembelajaran khususnya untuk konsep-konsep yang dirasa paling sulit bagi mahasiswa, dan penyusunan bahan ajar yang sesuai dengan tuntutan silabus yang disusun program studi.

\section{DAFTAR PUSTAKA}

Atagana, H., \& Engida, T. (2014). What Makes Chemistry Difficult? ASEAN Journal of Comunity Engagement, 4(May), 31-43.

Çalik, M., Ültay, N., Kolomuç, A., \& Aytar, A. (2015). A cross-age study of science student teachers' chemistry attitudes. Chemistry Education Research and Practice, 16(2), 228-236. https://doi.org/10.1039/c4rp00133h

Cheung, D. (2011). Evaluating student attitudes toward chemistry lessons to enhance teaching in the secondary school. Educacion Quimica, 22(2), 117-122. https://doi.org/10.1016/s0187893x(18)30123-x

Chiu, M. (2005). A National Survey Of Students , Conceptions In Chemistry In Taiwan. Chemical Education International, 6(1), 38. Retrieved from www.iupac.org/publications/cei

Daniel Tan, K. C., Goh, N. K., Chia, L. S., \& Treagust, D. F. (2001). Secondary students' perceptions about learning qualitative analysis in inorganic chemistry. Research in Science and Technological Education, 19(2), 223-234. https://doi.org/10.1080/0263514012008774 0

Emendu, N.B., Okoye, C. M. (2015). Identifying Problems Associated with Studying of. International Journal of Scientific and Research Publications, 5(6), 1-7. Retrieved from www.ijsrp.org

Gabel, D. (1999). Improving Teaching and Learning through Chemistry Education 
Research: A Look to the Future *. Journal of American College Health, 76(4), 548554.

Galloway, K. R., Malakpa, Z., \& Bretz, S. L. (2016). Investigating Affective Experiences in the Undergraduate Chemistry Laboratory: Students' Perceptions of Control and Responsibility. Journal of Chemical Education, 93(2), 227-238. https://doi.org/10.1021/acs.jchemed.5b0073 7

Hofstein, A., \& Mamlok-Naaman, R. (2011). High-school students' attitudes toward and interest in learning chemistry. Educacion Quimica, 22(2), 90-102. https://doi.org/10.1016/s0187$893 \times(18) 30121-6$

Holbrook, J. (2005). Making chemistry teaching relevant. Chemical Education International, 6(1), 3-8.

Jegede, S. A. (2007). Students' anxiety towards the learning of Chemistry in some Nigerian secondary schools. Educational Research and Review, 2(7), 193-197.

Kaptan, K., \& Timurlenk, O. (2012). Challenges for Science Education. Procedia - Social and Behavioral Sciences, 51, 763-771. https://doi.org/10.1016/j.sbspro.2012.08.23 7

Kousa, P., Kavonius, R., \& Aksela, M. (2018). Low-achieving students' attitudes towards learning chemistry and chemistry teaching methods. Chemistry Education Research and Practice, 19(2), 431-441. https://doi.org/10.1039/c7rp00226b

Manneh, I. A. (2019). Supporting Learning and Teaching of Chemistry in the Undergraduate Classroom. Universitetsservice US-AB, Stockholm, Stockholm.

Mokiwa, H. O. (2017). Reflections on Teaching Periodic Table Concepts : A Case Study of Selected Schools in South Africa. EURASIA Journal of Mathematics Science and Technology Education, 6(13), 1563-1573. https://doi.org/10.12973/eurasia.2017.00
Nakhleh, M. (1992). Why Some Students Don ' t Learn Chemistry Chemical Misconceptions. Journal of Chemical Education, 69(3), 191-196.

Özmen, H. (2008). Determination of students , alternative conceptions about chemical equilibrium: a review of research and the case of Turkey. Chemistry Education Research and Practice, 9, 225-233. https://doi.org/10.1039/b812411f

Salame, I. I., Sarowar, S., Begum, S., \& Krauss, D. (2011). Students, Alternative Conceptions about Atomic Properties and the Periodic Table. The Chemical Educator, 16(11), 190-194. https://doi.org/10.1333/s00897112375a, 16110190

Satilmis, Y. (2014). Misconceptions about periodicity in secondary chemistry education: the case of kazakhstan. International Online Journal of Primary Education, 3(2), 53-58.

Sirhan, G. (2007). Learning Difficulties in Chemistry: An Overview. Journal of Turkish Science Education, 4(2), 2-20.

Taber, K. S. (2008). Exploring Student Learning From a Constructivist Perspective in Diverse Educational Contexts. Journal of Turkish Science Education, 5(1), 2-21.

Taber, K. S. (2009). Challenging Misconceptions in the Chemistry Classroom: Resources to Support Teachers El repte de les concepcions alternatives en química: Recursos per ajudar al professorat. Educación Química, 4, 13-20.

Talanquer, V. (2011). Macro, submicro, and symbolic: The many faces of the chemistry "triplet." International Journal of Science Education, 33(2), 179-195. https://doi.org/10.1080/0950069090338643 5

Yiin, H. K. O. H. (2010). Misconceptions In The Teaching Of Chemistry In Secondary Schools In Singapore \& Malaysia. In Proceeding of The Sunway Academic Conference (pp. 1-10). 